\title{
Keep it in the family
}

\section{Genes and Behavior: Nature-Nurture \\ Interplay Explained \\ by Michael Rutter \\ Blackwell: 2006. 272 pp. \$24.95, £14.99}

\section{Svenn Torgersen}

Today, every generally well-informed person is familiar with the findings of genetic research. Not only do we read that genes have a big influence on the development of personality, intelligence, diseases and disorders, but we have even learned that political and religious orientations, such as being a hawk or a dove, are to a high degree influenced by our genes. Outstanding genetic researchers tell us that our family background is not important; it is our genes and our personal private experiences, friends and acquaintances that count. And discoveries of new genes 'for' various behaviours and disorders are proclaimed daily.

Michael Rutter, the renowned child psychiatrist, challenges many of these views in his new book, Genes and Behavior. Modestly, he announces "I am not trained as a geneticist but I have been a user of behavioral genetics for some 30 years and I have made myself informed about genetic mechanisms and genetic issues." The book leaves no doubt that he is informed and he gives an excellent popular introduction to genetics, including its most modern variants. He describes how the functional, biological effects of genes (gene expression) are influenced by factors outside the gene - both environmen-

tal conditions and other genes. He covers well the two topics of gene-environment correlation and interaction. The first arises as we select, shape and evoke reactions from the environment according to our genes, whereas the second deals with our genetic susceptibility to react to particular types of environment, or to put it another way: the effects of certain genes depend on the environment.

In addition, the book seeks to challenge the claims of those whom Rutter labels as "environmental evangelists" and "genetic evangelists". Environmental evangelists disregard the fact that genes influence behaviour, whereas genetic evangelists go in for hyperbolic claims about genetic research and the role of genes.

In Rutter's view, a lot of the findings in quantitative behavioural genetics are either mistaken or misleading, and those that are correct are not interesting. He maintains that all behaviours and disorders are influenced by genes, and that attempts to quantify their relative contribution are unimportant. He considers such findings to be at best a source of inspiration for hypotheses concerning what he thinks is really important - finding the causes of behaviour and its disorders through the study of gene-environment interactions and correlations.

Few in the field will agree with this conclusion. The numbers do matter. For example, if a disorder has a heritability of $80 \%$ and one identical twin has it, the other twin is 40 times more likely than a randomly selected unrelated person to have it too, assuming a prevalence of $1 \%$ for the condition in the population at large. In contrast, if a disorder has a heritability of $20 \%$, the identical twin is only three times more likely to get the disor-

Nevertheless, if family environment is so important, as Rutter believes it is, how do we then explain the findings that identical twins who are reared apart are almost as similar to each other as identical twins reared together? And why is there almost no similarity between adoptive relatives, whereas adoptedaway children are almost as similar to their biological mothers as if they had grown up with them? Rutter rebuffs this research on methodological grounds, holding that the samples are not representative, and even suggesting that many of the studies have not been published in peer-reviewed journals. A simple literature search would have revealed that more than a few studies of twins reared apart have appeared in peer-reviewed publications.

As one might expect, Rutter opposes claims that there is a gene 'for' a specific behaviour or disorder. Even when he accepts some of the results from studies that have detected such relationships, his opinion is that the pathway from the gene to actual behaviour is too long and complicated to make the connection definitive. Hence, the relationship between gene and environment is probabilistic and not deterministic, modified both by our will and ultimately - by the environmental conditions that interact with the genes. Discounting those adoption studies showing the limitations of geneenvironment interaction, he focuses attention on those that do demonstrate such an interaction.

Another prominent theme in the book is gene-environment correlations: that is, how genes come to shape our lives for better or worse. Rutter gives a thorough introduction to the state of the art in this field. This research is in accordance with Rutter's strong interest in social

der. Rutter's additional objection, however, that the magnitude of genetic effects depends on culture and time, is widely accepted in the field, and has inspired researchers to study culturally different samples, and even to include different time periods in their study designs.

Even worse in Rutter's opinion is the contention that the family in which you grow up does not matter much - within the normal range - for your personality development and mental health. Here, Rutter's viewpoint corresponds to common sense. Yet all researchers who have interviewed several sets of twins are struck by how different fraternal twins can be and how similar identical twins are.

One could concede that this effect is the result of gene-environment interaction, making genetically different fraternal twins react differently to the same family environment. issues and the conditions of people's lives. And, of course, the study of gene-environment correlations also forms an important part of Rutter's quest to find the causes of behavioural disorders.

If you want an inspiring contribution to the debate in this highly topical area of research and also want to learn about the most up-todate approaches to genetic research, then this is the book to choose.

In the early 1970s, Rutter became famous for challenging environmental determinism in his book, Maternal Deprivation Reassessed (Penguin, 1972). Now, more than 30 years later when, in his view, the opposite zeitgeist is about to prevail, he challenges the genetic determinists. He has closed the circle. Svenn Torgersen is in the Department of Psychology, Oslo University, Postbox 1074, Blindern, N-0317 Oslo, Norway. 